\title{
Conflicts of Interest and the Importance of the Organizational Variable: A Comparison Among Canada, the United States and Mexico
}

\author{
David Arellano-Gault*,1,3 ${ }^{,}$Laura Zamudio-Gonzalez ${ }^{2}$ and Walter Lepore ${ }^{3}$ \\ ${ }^{I}$ Public Administration, University of Colorado, USA, ${ }^{2}$ Social Sciences, Iberoamericana University, Mexico City, USA; \\ ${ }^{3}$ CIDE, Mexico, City, USA
}

\begin{abstract}
The aim of this document is to advance our understanding of the costs and perils faced by any country when looking for tackling real and possible conflict of interests among public officials. In effect, there are regulatory, organizational, and institutional difficulties and costs related with the implementation of reforms aimed to combat or prevent real and potential conflicts of interest. This discussion is vitally important above all to developing countries such as Mexico given that the effectiveness, cost and impact of this tool up until now applied to different countries has achieved rather heterogeneous results. The main objective of this paper is to enhance the importance of the organizational dimension whenever a regulatory framework to control conflict of interests is placed or implemented. Public organizations are not merely instruments adaptable to the orders and instructions stemming from regulations and rules. In this sense, the regulatory (both formal and "soft") framework should take in consideration the concrete organizational effects of the rules and institutions designed to change the behavior of actors. Developing a comparison of regulatory, institutional and organizational strategies applied in Canada, Mexico and USA we seek to show that the organizational dimension is critical in order to understand the "real" net effect achieved when dealing with complex behaviors like the ones which drive social and political actors to face conflict of interests situations.
\end{abstract}

Keywords: Conflict of interest, corruption, public orgnizations, Mexico.

\section{INTRODUCTION}

Over the last thirty years or so the literature specialized on management and public policy has been seemingly dominated by the debate on New Public Management. Often enough, the focus of this debate has centered primarily on the analysis of questions such as the efficiency, effectiveness and productivity of government action. However, despite the effort made to consider this debate as one that is largely "technical" in nature, the moral and ethical aspects of this argument that go hand in hand with public action have not escaped discussion either. The (re)incorporation of certain fundamental yet widely disputed values -such as justice, equality and the equal treatment of citizens- to the discussion on paper of public management in a liberal democracy has been the main preoccupation of a number of specialists on the matter (Wade, 1992; Anderson, 1992; Frederickson, 1997; Gregory,1999; Ventriss, 2000; Kliksberg, 2006; amongst others). The ethical standards of public management in this field continue to be disputed. Nevertheless, it has become more and more apparent that the intention to make them instrumental collides systematically with the diversity and uncertainty inherent in the relations and constructs generated within government organizations.

All government intervention potentially implies that multiple interests will be affected. As a result, the discussion of

*Address correspondence to this author at the Public Administration Division. Carretera Mexico Toluca 3655. DF Mexico 01210, USA; Tel: (5255) 57279805, USA; Fax: (5255) 57279805; E-mail: david.arellano@cide.edu; E-mail: gaultin@gmail.com values and ethical standards is a fundamental requirement to facing these challenges effectively. It could be said that the ultimate goal is to create and maintain confidence that the government makes its decisions objectively, or at least impartially (Thompson, 1992).

A particular focal point in the discussion with respect to the construction of good government from the viewpoint of the debate on ethics is that related to combating and preventing conflicts of interest of public officials. In other words, prevent the "intromission" of private interests in the performance of government activities and control the interrelation between public officials and actors outside the government apparatus who may undermine their "good judgment" or lessen their desire to perform correctly and in the public interest. The last few decades have seen this problem take greater relevance as a result of the increased participation and hiring of the private sector to carry out government activities, wider diversity of government functions and greater discretion granted to public officials to better allow them to improve their performance (Graham, 1974). For these reasons and in view of the likelihood that these types of reforms in the style of New Public Management have increased the impact of external influences on the behavior of public officials, creating and maintaining public confidence in the integrity of the government apparatus is a primary concern once more.

The aim of this document is to enhance the critical importance of the organizational variable when building regulations and designing institutions to deal with conflict of interest in the public sector. This discussion is vitally important above all to developing countries such as Mexico given that 
the effectiveness, cost and impact of formal regulations until now applied to different countries has achieved rather heterogeneous results. Formal regulations and institutional incentives are actually implemented and used within organizational arenas. Organizations are then the space where these regulations and incentives do actually evolve and generate their (expected and unexpected) effects. Developing regulations and institutions therefore, imply a critical understanding of the costs and perils these instruments will face once they have to be implemented in concrete organizations. In order to observe the interaction of regulatory, institutional and organizational elements, our study starts with an analysis of international experiences, in particular those of the United States of America and Canada, where a vigilante framework for action has been constructed (relatively realistic and viable, although not exempt from practical problems) to attend to the resolution and prevention of conflicts of interests that arise in the government arena. With respect to the regulatory arena, we shall focus our attention on the kind of formal regulation, its scope and the type of sanctions that have been applied in these countries in order to discuss their effectiveness. Regarding the question of institutions, our analysis centers on the type of structure (centralized or decentralized) that these countries have used to provide order, attend to and follow up on conflicts of interest. Finally, in relation to the organizational aspects, we shall look at the different organizations entrusted with overseeing compliance with regulations and the application of sanctions, its functions, powers and the mechanisms for control to battle and prevent conflicts of interest. Our emphasis is to show the practical and theoretical importance of the organizational elements in their interrelationships with regulatory and institutional efforts, when dealing with the construction of a integral framework to deal with conflict of interests in the public sector. ${ }^{1}$

In view of the above, this document is structured in the following manner. The first section is dedicated to conceptualizing as precisely as possible what we understand by "conflict of interest", what characterizes potential, real and apparent conflicts, and the difference between conflicts of interest, corruption and influence peddling. The second section shall focus on the difficulties with preventing these conflicts once the organizational dimension is factored into the analysis. Without doubt, an in-depth look at the subject of conflicts of interest from a regulatory, social and political point of view would be useful to capture an outline of the general characteristics and consequences of this type of phenomenon. However, our main focus is not the regulatory challenge, understood as the effectiveness of government regulations to change behaviors and adapt them to pursue collective or social objectives (Levi-Faur, 2005; Majone, 1997). Our focus is rather organizational: seen as social constructs made up of people with diverse values and interests (including conflicting ones) and therefore where the possibility of conflict between the members of the organization and others are ever present. As a result, if our intention is to advance the study of conflicts of interest in a practical and useful (not

${ }^{1}$ It is worth keeping in mind that this document studied conflicts of interest that arise in the arena of the Federal Executive Branch, its cabinet and high ranking officers (as well as those appointed directly such as in the civil service). This does not mean that the conflicts of interest that may arise in the Legislative and Judicial Branches do not merit detailed attention, just that they are not the aim of this particular analysis even though we hope that the organizational lessons put forward here may be useful in the discussion on these institutions. just prescriptive) manner, it would be necessary to understand the complexities and peculiarities that arise within public organizations in order to face and prevent conflicts between their members. Continuing with the structure, in the third part of this document we look at the experiences of the United States of America and Canada with the intention of comparing them with the regulatory and legal instruments that have been tried here in Mexico. The fourth section is dedicated to the organizational and institutional aspects taken from the experiences of these other countries while the fifth section briefly presents some mechanisms for organizational control that have arisen out of these same international experiences. The last section of the document reveals the most relevant findings and potential risks that the control and prevention of conflicts of interest that can come up in developing countries such as Mexico.

\section{CONCEPTUALIZING CONFLICTS OF INTEREST}

This section is aimed at giving the reader a first look and basic understanding of what is known in the literature as conflicts of interest. Firstly, it is necessary to understand that conflicts of interest represent a politically and socially complex phenomenon that is difficult to define with absolute certainty and accuracy. For example, the OECD defines conflict of interest as "a conflict between the public duty and private interests of a public official, in which these interests could improperly influence the performance of his or her duties as a public official" (OECD, 2005: 2). While in generic terms this definition seeks to grant clarity, organizational implementation of this definition is somewhat imprecise with respect to what is understood by: "improper influence", "ability to influence", "conflict between private interests and public duty" (Arellano-Gault and ZamudioGonzalez, 2009). The definition put forward by the New York County Lawyer's Association is equally as broad, which understands conflict of interest as "the risk [that may arise] of impairment in producing an impartial opinion; the ever-present risk of the temptation to serve one's personal interests" (Anechiarico and Jacobs, 1996: 46). As in the previous case, this definition requires greater clarity in order to implement concepts with relative and ambiguous meanings such as "impairment", "impartial" and "personal interests".

A more precise meaning (and one more useful for this document) is provided by Roberts (2001) who considers that management restrictions and criminal penalties aimed at preventing conflicts of interest and protecting the impartiality and objectivity of the government apparatus must focus on the following actions: (1) gifts from outside (nongovernment) sources, (2) gifts from one public official to another, (3) financial interests in conflict, (4) employment and activities undertaken outside government, (5) improper use of authority (position), and (6) [post employment] restrictions on ex-public officials (Roberts, 2001: 74). This reconciliation with the term is largely procedural and is widely used in different regulations around the world despite it being unclear on how it is possible, practically speaking, to construct an apparatus of regulations to supervise these situations effectively and viably.

In spite of this battlefield demarcation where it is necessary to prevent and control conflicts of interest, the matter becomes even more complicated when this definition allows 
us to speak about real, potential and apparent conflicts of interest. Real conflicts of interest are those where the pursuit of the personal (and family) interests of the public official have a genuine and apparent bearing on their performance or personal motivation to act correctly in the public interest. Potential conflicts of interest arise in situations where the conflict is not yet evident, but in the future, given the right set of circumstances that may change according to the public official, this conflict could manifest itself. Lastly, apparent conflicts of interest are those where the presence of a conflict is suspected (even though this does not exist), which in turn affects the image of the public official and in particular, the confidence in the government apparatus in general.

It is worth pausing briefly over this last type of conflict of interest in order to understand the importance of appearances (or what has come to be known as "standards of appearance"). According to these standards, "the appearance of acting improperly when in fact you are acting correctly is in actuality to act improperly" (Thompson, 1992: 257). As this author points out, public officials who give the appearance of acting improperly are effectively committing "moral errors" because they provide citizens with reasons to act distrustfully with respect to the government and more importantly, undermine the rendition of democratic accounts. Resultantly, these appearances and perceptions are quite often the only windows available to the citizenry to observe the conduct of their public officials. To reject these standards of appearance would therefore imply a rejection of the possibility of rendering accounts in a democratic regime (Thompson, 1992). ${ }^{2}$

This last example is a good summary of the practical complexity of facing conflicts of interests: it is clear that to create institutions and organizations to confront them efficiently and viably, one must face the enormous difficulty of precisely defining the boundaries between the real, the potential and the apparent. This is because the line between a person's labor and knowledge, as well as their marginal contribution to an organization are hard to establish. It is also due to the fact that interests, broadly defined, form part of human nature, and from a liberal point of view there is no strict sense of "bad" or "good" interests with respect to regulations (Arellano and Zamudio, 2009). Additionally, we should no forget that the management apparatus, and what is more, our elected representatives, are actors in a specific political context, which often sees the battle against conflicts of interest used as a political weapon against their adversaries.

In our efforts to pursue clarification of certain concepts, it is worthwhile determining how these different conflicts of interest relate to corruption. Generally speaking, corruption is a complex concept; it does not imply a predefined form of behavior or even a specific type of conduct, instead it applies to certain types of reciprocal relations between some indi-

\footnotetext{
${ }^{2}$ One of the main objections made to the standards of appearance is that their definition is highly subjective: what appears incorrect to some people may appear correct to others. This may have a negative effect on the vulnerability of public officials given that they could be subjected to unfair punishment, depending upon who evaluates their actions. Thompson (1992) however, argues that the standards of appearance can be defined objectively if they are upheld by empirical regularities. This implies long term observation of certain types of practices that have led to improper actions on the part of a public official, and later condemn these practices regardless of whether they currently result in wrongful acts.
}

viduals in a defined context and period of time (Anechiarico and Jacobs, 1996). As these authors point out, criminal codes often refer to the idea of corruption as improper practices such as offering and accepting bribes, extortion and robbery; however, there is no similar and unerring definition of the crimes linked to fraud, to illegally accepting money, to conflicts of interest, false declarations and the illegal financing of political campaigns, just to name a few.

Corruption therefore is a broad concept which includes conflict of interest even though it is not exclusively limited to these types of practices. Conflicts of interest can lead to acts of corruption, but not always, this being its main difference. Indeed, the OECD (2005) accepts that not all conflicts of interest constitute acts of corruption, except in those cases where conflict arises between private interests and capacities which sees the effectiveness and appropriateness of an official's performance and decision making in the public arena influenced in order to benefit either them personally, their families or some other third party with whom there is some kind of relation (these types of situations are what we refer to in this document as real conflicts of interests). When you look at it this way, all public officials have private rights and interests, this being part of their inescapable human nature. Conflicts of interest then are potentially constant, ongoing. The main reason behind tackling conflicts of interest therefore, lies in our efforts to prevent a potential conflict of interest from becoming an apparent or real conflict of interest, such as a consummate and apparent act which affects the integrity and objectivity of the government apparatus. The primary concern then in respect to conflicts of interest would be: to prevent or reduce the possibility that the judgment of public officials or politicians is "handicapped" or otherwise compromised. It is clear however, that within the organizational battle to control these conflicts, an important part (if not the only one) lies in the capacity to find, identify and punish real conflicts of interest, which in fact are much closer to acts of corruption.

In respect to the relation and difference between conflict of interest and influence peddling for example, the Mexican Federal Criminal Code (chapter IX) lists as influence peddling the following: 1) a public official who on their own behalf or that of a third party, encourages or arranges the illegal processing or resolution of public business outside the responsibilities inherent to the job, position or charge corresponding thereto; 2) any person who supports the illegal conduct of the public official or assists in encouraging or processing of the abovementioned; and 3) a public official who on their own behalf or by way of a third party, improperly requests or encourages any resolution or carries out any act related to the job, position or charge of another public official which results in an economic benefit to themselves or their spouse, decedents or ancestors, relatives by blood or other kinship to the fourth degree, or to any third party with whom they have emotional, economic or direct links to the management, partners or companies of which the public official or abovementioned persons form part. ${ }^{3}$ As you may

\footnotetext{
${ }^{3}$ The Mexican Federal Criminal Code establishes that a person guilty of the crime of influence peddling shall be sentenced to two to six years in prison and receive a fine ranging from thirty to three hundred days minimum daily salary valid and in force in the Federal District at the time the offence was committed. Moreover, they shall be removed from public office and barred from holding any government job, position or charge for between two to six years.
} 


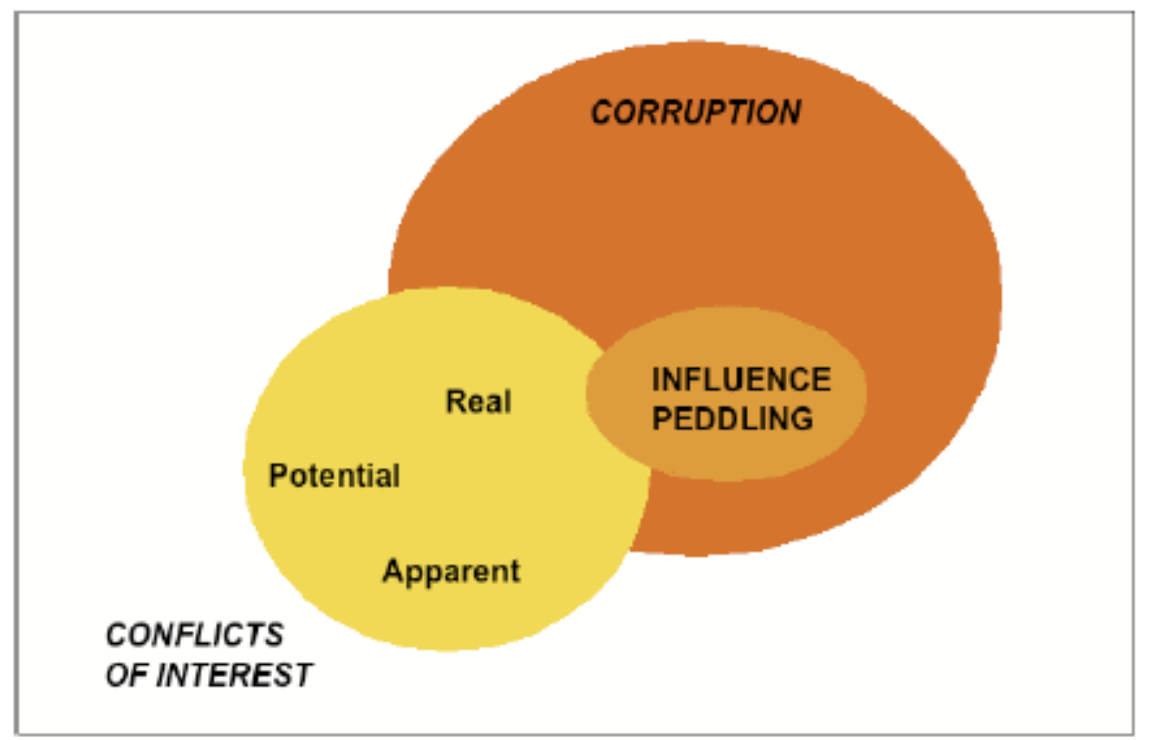

Source: Own

Fig. (1). Relation between conflicts of interest, corruption and influence peddling

have noticed from this particular regulatory definition of influence peddling, this type of crime constitutes an act of corruption and is directly linked to real conflicts of interest; in other words, consummated acts that have sought and/or managed to influence the decision making processes of a public official for their own personal benefit or that of others with which there is some kind of family, emotional or labor relation. Despite its direct link to real conflicts of interest, the definition of influence peddling does not consider problems between private and public interests where the conflict may appear to be potential or apparent. It could be argued starting with the actual definitions of conflict of interest (as well as their diverse types) that they represent a much broader concept than influence peddling and therefore, its prevention and correction can not be limited to the criminal sanctions established in the Criminal Code, as is the case in Mexico.

Fig. (1) graphically synthesizes the relations between conflicts of influence, corruption and influence peddling described in this section.

From this diagram, acts of corruption encompass a series of improper practices that vary widely in nature. Those linked to influence peddling and real conflicts of interest are just some of the ways these types of acts are manifested. Similarly, certain real conflicts of interest could be categorized as influence peddling, although their meaning and the way they are demonstrated is much broader and diverse thereby requiring different treatment. Lastly, conflicts of interest that have not yet manifested themselves (whether apparent or potential) are not considered as corrupt practices -in the traditional sense of the definition- since they do not emotionally or improperly influence performance and decision making in the public arena. Understanding these differences is the first step towards designing mechanisms and systems to prevent and resolve conflicts of interest in a practical manner which goes beyond regulatory frameworks (be they criminal or administrative) and allow us to confront this complex phenomenon.

\section{MEASURING CONFLICTS AND INTERESTS FROM AN ORGANIZATIONAL VIEWPOINT}

Another aspect to consider in our effort to conceptualize conflicts of interest refers to the inherent and unavoidable presence of opposing, overlapping or divergent interests between members of any organization (be it public or private). Organizations are social creatures supposedly built by us and implemented to follow our instruction. In reality however, they have become entities requiring sophisticated management, and have even developed somewhat a rebellious nature.

The study of organizations ranging from a social perspective through to an economic standpoint has documented how organizations have become unwieldy and technically complex. Individuals within organizations often manage to create agreements in spaces of limited rationality (Simon, 1947). As a result, there is no way of finding out or even calculating to any measure of perfection the consequences of the acts and decisions of these and of other actors. Uncertainty therefore is constant and ongoing in organizational logic. This implies that actors build mechanisms to get around it since it is ubiquitous and can never be fully eliminated. Amongst these mechanisms the executive branch is the first line of defense: it controls the most important arenas of uncertainty within a defined context, acquiring a significant source of power. Uncertainty is the foundation of power for all social agents. Additionally, this implies that social actors may strategically seek to widen specific types of uncertainty in order to create power mechanisms or to build symbols and common values within an organization that allow cooperation between different actors who are potentially in conflict. Uncertainty then is a pathological element that needs to be eliminated, a strategic instrument employed by actors in spaces that grant a certain freedom and autonomy; the discretion for actors to act, which is what it is all about (Crozier and Friedberg, 1989). When looked at in this manner, discretionality to a certain extent is a vitally important criterion for 
making organizations work. ${ }^{4}$ No society can realistically eliminate such a space of freedom for its politicians and public officials since the great majority of this capacity for conflictive interaction leads to attitudes and behavior often linked to merit and effort such as acquiring knowledge, acting strategically, making decisions, searching for solutions and being innovative (Arellano and Zamudio 2009).

Thus, from an organizational standpoint, not only are conflicts of interest ever present, but they also form part of the strategic games that actors use to mobilize awareness, build psychological frameworks and organizational actions, symbols and values for cooperation and collective action all within this constant state of uncertainty (Crozier and Friedberg, 1989). As you will come to appreciate, this radically changes the way we understand diverse political and organizational dilemmas (conflicts of interest being among them) since starting by assuming that discretionality and uncertainty are failures which must be attacked instrumentally -as we would a pathogen- would further our understanding of them even though it would probably be much less effective in terms of organizational actions to control and channel them (March and Olsen, 1979; Brunsson, 1989).

As a consequence, when we speak of conflicts of interests in a framework of political action taken by public officials who were duly appointed or elected in a liberal democracy, or for that matter politicians in general, these generic, organizational and social elements do not disappear, they simply become more specialized and intricate (ArellanoGault and Zamudio-Gonzalez, 2009). This is because conflicts of interest go hand in hand with another highly abstract concept called "public interest" (Williams, 1985). In other words, one may well outline an argument based largely on regulation concerning conflicts of interest in politics or government acts whereas in practice, these regulatory elements have to face up to the social realities of diverse actors each with a differing framework of uncertainty and the knowledge that government organizations are really managed surreptitiously of the actor's strategic actions (Arellano-Gault, 2000). As Stark (1997) clearly argues, no formal regulation can prevent the interests of public officials from appearing or being measured in such a way that their judgment seems to have been affected. Regulations regarding these matters have evolved towards prohibiting development of certain types of interests in general in order to prevent the formation of relations where there is a temptation to succumb to conflict. One thing remains clear, currently there is no better option; conflicts of interest are constant and ongoing, as difficult to measure as they are to define.

Keeping in mind the organizational complexities that review this phenomenon, a formal regulatory vision is both essential, yet insufficient. In practice, we cannot confront these types of conflicts with moral conviction or ethics alone. This is because conflicts and interests are influenced by subjective definitions, which implies that they can never be completely and clearly defined, and the lack of a clear boundary between the "correct" and "incorrect" interests. Moreover, an infallible mechanism or instrument that would

\footnotetext{
${ }^{4}$ Diverse trends in organizational analysis have highlighted the importance of discretionality as a criterion for making organizations work. The bibliography could be immense; among them we recommend Christensen and Laegrid (2001), Williamson (1983), Pfeffer (1994), Scott (2000) and Luhmann (1997), to name a few.
}

allow us to "measure" or recognize whether an actor seeks specifically and fraudulently to proceed contrary to general interests is even less likely in practice (as a result of serious problems with empirically defining and "observing" both affective individual interests and socially affective interests). In organizational terms, the key is understanding that actors make strategic decisions according to the cultural context and the rules already in place. Not only do these rules restrict behavior, but they also generate "signals" or positive incentives that encourage certain types of actions. Conflict of interest then is a question that might never enjoy a perfect, working definition in any practical sense due to the subjectivity and ever changing interests of social agents. Conflict of interest therefore is not just a battle fought under the universal guise of "good" and "bad", but a struggle to build up organizations and institutions of a specific nature that determine the reality in which actors can act symbolically and genuinely. "Soft" regulations might be of importance here, looking to create structures of incentives to push for autoregulation. However, the introduction of the ideas of softregulation is something still to be done in the topic of conflict of interest (Atkinson and Mankuso 1991; Ahrne and Brunsson, 2004).

Three elements appear to be critical when it comes to understanding to question of conflicts of interest: (1) the need to discuss regulations that protect society from the conflicts of interest that its public officials and politicians regularly suffer when they act; (2) the complex reality that conflict is, by definition, intrinsic to politics in liberal societies; and (3) the strategic actions of politicians and public officials are fundamental pillars of organized government action. This posture (however realistic it may be) does not seek to completely nullify conflicts of interest or control them with a blanket approach, but instead prevent and reduce their occurrence as much as possible to manageable levels so that they do not affect government action and above all, public confidence.

\section{REGULATORY EXPERIENCES}

After having made much progress in conceptualizing the different types of conflicts of interest and the complexity involved in identifying and measuring it in practice (especially from an organizational point of view), it is worthwhile analyzing the experiences of the United States (USA) and Canada in order to identify the regulatory tools that these countries use to prevent and control these conflicts, as well as compare and contrast them with Mexico. It is worth remembering that the government regimes of the United States and Canada differ (a presidential system versus parliamentary system respectively) and these structural differences determine the type of regulation and regimen applied in each case to combat conflicts of interest (Stark, 1992).

In first place, it should be pointed out that both the United States and Canada have at their disposal a heterogeneous collection of regulations and laws whose purpose is to prevent conflicts of interest and regulate financial disclosure. These regulatory and legal frameworks make up an administrative/criminal code that applies solely to public officials. One important difference between the two countries, given their different systems of government, is that the United States has specific regulations for each executive branch while Canada establishes common 
while Canada establishes common regulatory tools (although with some slight differences) for its ministers, cabinet members and members of the lower house of Parliament.

Despite these differences, both countries share the same objective: to combat conflict of interest, preventing it and its spread, and denying it the opportunity to materialize as consummate fact thereby undermining public confidence in the government. The main objective therefore, is not to detect and punish improper acts, but to operate as a type of "lifeguard" which reduces the risk and prevents undesirable behavior from happening (Anechiarico and Jacobs, 1996). In the case of Canada, the spirit of their regulation has gambled on establishing from the very beginning and for their public officials at all levels, the type of obligations and risks they may come to face. The purpose of this is to foster a clear awareness of conflicts of interest, as well as to take preventative steps and inform public officials prior to them assuming office. Similarly, the declaration ex ante made by public officials in response to their obligation towards information and behavior appear to be a critical element in the constant supervision against present and future conflicts of interest.

In the case of our northern neighbor, the USA, prevention is an important element in the regulatory framework tasked with supervising conflicts of interest, just as it is in Canada (there are similar regulations with respect to public officials who must relinquish certain recourses, actions or positions in private organizations that may create conflicts of interest). Nevertheless, regulation in the United States has gambled on supervision by diverse agencies (Atkinson and Mancuso, 1991) and a broader collection of laws and regulations. This last point seems to be of great relevance to this country if we accept that it is impossible for a solitary regulatory agency and a single, albeit homogeneous collection of laws and regulations to be sufficient enough to identify and monitor possible cases of conflict of interest (Arellano-Gault and Zamudio-Gonzalez, 2009).

Arellano-Gault and Zamudio-Gonzalez (2009) point out that, contrary to the previous cases, prevention does not appear to be the founding logic behind the greater part of the regulations here in Mexico as their wording is highly regulatory in nature (in other words, under the premise of "must be"). A preventative and pragmatic spirit does not seem to be the strongpoint of these regulations which do not put forward the possibility that to prevent a conflict one must reduce the probability of it happening. The posture of Mexican legislation is largely one that prohibits certain specific acts, sets out explicit mechanisms to supervise and punish, and places bans on discreet events; all under the logic of reduced prevention. According to federal laws which regulate the responsibilities of public officials, they must "abstain" from practices that imply conflict of interest; ${ }^{5}$ however, these regulations do not establish specific mechanisms and systems to verify compliance with legal provisions on the matter or to reduce the probability of conflicts arising. This is quite different to Canada and the USA which have progressed towards a more pragmatic vision of conflict of interest to understand that this phenomenon is an inevitable and

\footnotetext{
${ }^{5}$ For more details, see the Art. 8 of the Ley Federal de Responsabilidades Administrativas de los Servidores Públicos (Federal Administrative Duties of Public Officials Law) and Art. 47 of the Ley Federal de Responsabilidades de los Servidores Públicos (Federal Conduct of Public Officials Law).
}

ongoing influence on the activities of every public official. Put in other words, the case here in Mexico seems much more focused on punishing consummated conflicts of interest (real ones). The experiences of the USA and Canada on the other hand seek to prevent and correct potential and apparent conflicts before they manifest themselves and begin to affect the integrity and objectivity of the decision making process and of government action. Seeing as though conflicts of interest are so complex to define and measure, and practice has shown us that interests are dynamic and measuring "improper influence" is complex to establish, Mexico's experience faces a serious limitation: simple regulation, stuck in a vision of discreet events involving regulatory infringements, is highly restricting of progress towards building tools that allow public officials to confront these conflicts and know how to act in the face of complex ethical dilemmas (Gillman, Joseph \& Raven, 2002).

Conscious of these limits, both the USA and Canada have elected to combine a number of different ways to address conflicts of interest, these being statutory and nonstatutory regimens; the last of which is practically absent in Mexico (except in some cases such as "code of ethics"). Statutory regimens are understood as the legal and regulatory mechanisms and sanctions established to prevent conflicts of interest, but more to the point, to punish and resolve them. On the other hand, nonstatutory regimens are not just limited to codes of ethics, but seek to build organizational structures capable of supervising, educating, supporting, as well as fulfilling the role of information centers to better understand the phenomenon and its sources. In the case of North America, criminal statutes that regulate conflicts of interest are complemented and bolstered by standards of ethical conduct that apply to officials of the Federal Government and Legislature (emanating from the Executive Orders of the Executive branch). ${ }^{6}$ These ethics standards are directly linked to the complicated question of appearances, which we mentioned earlier.

One relevant aspect to keep in mind given the presidential system and the distribution of powers in the USA is that the content and application of regulatory restrictions to conflicts of interest in the different branches of the federal government are determined by the Congress. It is possible therefore that there is no parity between the regulatory burden that this imposes on the Executive Branch and that which is "self-imposed" in order to prevent conflicts of interest in the Legislature (Stark, 1992). As this author indicates, the reverse is true for Canada given the superposition of powers and control of the legislative agenda enjoyed by the Prime Minister and his/her Cabinet. The Canadian regulatory regimen seems to be aimed at imposing administrative and criminal burdens fairly on cabinet members and the remaining members of parliament. In comparison, Stark (1992) goes on to point out that in the USA, regulatory restrictions more often fall on the cabinet members of the Executive Branch while Congress attempts to free itself from them.

In respect to nonstatutory regulations, the opposite tends to be the case. For instance, in the USA the balance is relatively even between the rules, codes, regulations and guides for ethical conduct which apply extensively to both the Ex-

\footnotetext{
${ }^{6}$ For example, Executive Orders 11222 and 12674 dated 1965 and 1989 respectively.
} 
ecutive and Legislative Branches. On the other hand, not only are there less nonstatutory restrictions in Canada, there is a disparity between the burden these place on both branches with those applying to Parliament being less strict (Stark, 1992).

We have already mentioned that the Mexican regimen demonstrates a clear tendency to combat (real) conflicts of interest primarily by way of regulatory sanctions (administrative, economic or criminal) which punish specific improper or illegal actions. However, this regimen lacks the nonstatutory elements that prevent apparent and/or potential conflicts of interest which at the same time transversely cross all three federal branches. Progress in this direction would allow the construction of a common base of conduct so that each public organization would be able to perform its duties in the public interest in strict accordance with the highest standards of ethical conduct.

Having arrived at this point, it remains impossible to formulate a clear and decisive recommendation in this respect apart from the experiences of Canada and the USA; however, we can at least put forward the following. In the case of Mexico, any specific combination of statutory and nonstatutory regimens must take into consideration the underlying structural configuration of the relative strengths and abilities of the Executive and Legislative Branches. The motive for this would be to see that criminal and administrative burdens, codes and rules for ethical conduct are allocated fairly, but also to establish mechanisms to ensure they are complied with.

\section{ORGANIZATIONAL AND INSTITUTIONAL EX- PERIENCES}

We mentioned beforehand that prevention and control of conflicts of interest need to go beyond regulatory frameworks and lead the discussion toward an organizational and institutional approach. In this section, we shall focus our efforts on analyzing the experiences of the USA and Canada, and contrast them with Mexico in order to identify the types of organizations in place there which constantly supervise conflicts of interest that may arise, as well as the capacities, functions and inter-organizational relations they have established.

\subsection{Office of Government Ethics (United States of Amer- ica)}

In the USA, the Ethics in Government Act enabled the creation in 1978 of the Office of Government Ethics (USOGE) to supervise the management of ethics programs within the federal government. Initially, this body formed part of the Office of Personnel Management, but by presidential decree in 1989 it was established as a separate agency so it could exercise more autonomous leadership and enjoy greater capacity to prevent and resolve conflicts that arose. ${ }^{7}$ Among its primary tasks were those linked to fostering high ethical standards of conduct and strengthening the public's confidence that government action is taken impartially and

\footnotetext{
${ }^{7}$ A special office has been established in the USA to resolve conflicts of interest for the Legislative and Judicial branches. The Senate Select Committee on Ethics and the House Committee on Standard of Official Conduct were created for the Legislature while the Judicial Conference Committee on Code of Conduct was established for the Judiciary.
}

with integrity (USOGE, 2006). With this purpose in mind, the USOGE has been entrusted to issue extensive guidelines for conduct linked to a broad spectrum of government ethics questions, such as accepting gifts, employment outside the government sector, improper use of government information and financial conflicts of interest. Similarly, this office has the ability to request corrections to regulations or ethics policies, and undertake education and training programs to facilitate understanding and application of programs, regulations and ethics codes for the Executive Branch. One of the main tasks of the USOGE also consists in supervising public financial declarations of presidential appointees subject to the approval and confirmation of the Senate in order to prevent conflicts of interest before the official takes office.

Inter-organizational relations are vital to the USOGE given that they allow it to fulfill its duty to prevent, supervise and resolve conflicts of interest. The operation of ethics programs and, in particular, the day to day supervision and prevention of conflicts falls to the Designated Agency Ethics Officials of the federal government agencies (DAEO). DAEO are formally appointed by the head of each federal agency and are directly responsible for the ethics programs in these agencies. The labors of the USOGE depend largely on the DAEO who have more intimate knowledge of the official duties of each public official in the agency, the specific statutes and regulations that govern conflict of interest and the circumstances that could give rise to them as a result of the declarations of information and financial interests provided by these same officials (Walter, 1981). In this way, the USOGE can keep its ethics programs operating (especially prevention tasks) in a decentralized structure. On the one hand, this structure grants responsibility to the person in charge of each agency for the integrity and honesty of its employees, and on the other, through working together with other agencies and the USOGE, allows any conflicts of interest to be identified and resolved as quickly as possible. Thanks to this decentralized management structure, the USOGE has also been able to increase its ability to exercise preemptive judgment regarding potential conflicts of interest that may arise between the public and private arenas. A fundamental aspect of the inter-organizational relations between the USOGE and government agencies are the extensive programs that provide training workshops for the DAEO and all employees and officials of federal agencies. This allows them to increase the effectiveness of the ethics programs for each department (Roberts, 2001).

Regarding, the control of compliance with the regulations governing conflicts of interest, the processing of officials for violations to the statutes and the resolution of real conflicts of interest (understood as improper conduct on the part of the official), the USOGE leaves responsibility for these actions to the Unites States Department of Justice (department of Public Integrity) and the corresponding Office of the Attorney General according to the specific attributes of each. This is mainly due to the fact that since its creation, the USOGE was not authorized to investigate allegations of wrongful conduct of federal agencies and their employees. The investigation of federal officials falls upon the Inspector General of the department or agency implicated, and whenever necessary, the FBI (which answers to the Justice Department). 


\subsection{Office of Ethics Committee (Canada)}

Canada has also elected to establish organizations with a certain degree of autonomy entrusted with creating mechanisms to prevent, maintain and release information, carry out supervision and attend to the criminal and administrative consequences should conflicts of interest arise. In 2004, the Office of Ethics Commissioner (OEC) was created as a result of reforms to the regimen of conflicts of interest at the federal level, which provided for an extensive legal framework for members of Parliament (members of the House of Commons and senators) and Public Office Holders. This office is an independent parliamentary body that reports directly to the Executive Branch.

The main duties of the OEC consist, on the one hand, of managing the Conflict of Interest Code for members of the House of Commons; maintain records of the financial dealings they reveal, as well as their Confidential Certificate of Interests; ${ }^{8}$ administer the Conflicts of Interest Codes and Post-employment for Public Office Holders; and maintain the public registrar of these officials including Ministers and parliamentary secretaries. Secondly, the OEC provides confidential opinions to members of the lower house of Parliament and advises Public Office Holders on questions related to their obligations on these matters. Lastly, the OEC is able to conduct investigations on behalf of Parliament concerning compliance with the regimen of conflicts of interest at the request of members of the Executive Branch or the public service. In order to comply with these duties, the OEC also undertakes educational initiatives and communication activities to inform their clients (members of the House of Commons and Public Office Holders) and the general public (OEC, 2006). OEC function and achievement of its objectives is founded on the principals underlying the modifications to the regimen of conflicts of interest carried out in 2004: a) the independence of the office in respect to of a statement of account to Parliament, and b) transparency of the new regimen, which is accomplished by way of making details regarding Public Office Holders public.

With respect to inter-organizational relations, the structure of the OEC for preventing and resolving conflicts of interest is more centralized than that seen in the USA. This is due to the fact that the OEC deals with problems that may arise in the Executive Branch and the lower house of Parliament whereas the USOGE attends exclusively to conflicts of interest with the Executive Branch. This difference is due mainly to the different systems of government between Canada (where the cabinet is formed from members of the lower house) and the USA (where the cabinet is appointed by the President of the Republic). Moreover, the more centralized structure of the OEC also enjoys powers to investigate improper conduct and noncompliance with regulations which are nonexistent in the USOGE. These attributes are limited to the Department of Justice and the Attorney Generals Office. Despite these differences, this does not imply that the Canadian OEC operates completely independently and disconnected from the rest of the federal public administration.

\footnotetext{
${ }^{8}$ Confidential Certificate of Interests is a declaration made by all public officials which they must deliver to this office. It is an extensive statement of the persons, interests, employment, participations in companies and their board of shareholders, as well as all potential relationships that may impact negatively on his/her activities as a public official.
}

In its first two years of life, the OEC has maintained professional relations cooperating with diverse committees of the House of Commons, such as the Committee on Procedure of the lower house and the Committee on Access to Information, Privacy and Ethics of Public Office Holders (OEC, 2006).

The efforts of the OEC in respect to resolution of conflicts of interest are complemented by an independent Commission on Conflicts of Interest made up by three persons. This Commission is empowered to give opinions and advice on the actions of members of the federal government who may cause conflicts of interest; provide recommendations on the divestiture of certain assets and resources that cause conflicts; certify whether specific private interests of public officials are permitted; as well as retain or deny certification if public officials do not comply with the recommendations issued by the Commission. According to the duties and tasks of this independent commission, the resolution of conflicts of interest in Canada would seem to be based on jurisprudence and somewhat oversubtle analyses. This differs significantly to the USA where resolving a case of conflict of interest can be taken all the way to the Supreme Court, which imparts more of a legalist approach that tends to polarize matters in (abstract) terms of individual rights versus legitimate power of the State (Stark, 1992). While these considerations are not absent in the resolution of conflicts in Canada, this abstraction can be softened to some extent by adopting a more pragmatic approach to the circumstances and visible results of the actions or behavior the court is ruling on.

\subsection{Ministry of Public Duty and OICs (Mexico)}

After analyzing the experiences of the USA and Canada regarding organizational and institutional design to prevent and resolve conflicts of interest, we find numerous and substantial differences with the case in Mexico. Firstly, the greatest responsibility for controlling conflicts of interest in Mexican public administration falls on Internal Control Bodies (OIC by its initials in Spanish), which report to the Federal Ministry of Public Duty (SFP by its initials in Spanish). This aspect entails a different organizational and institutional approach to dealing with this phenomenon. Arellano and Zamudio (2009) point out that while Canada and the USA confer some measure of autonomy to combating conflicts of interest and performing precise activities stable over time, in Mexico the main duty of OICs are to constantly audit all federal organizations in respect to compliance with the regulations on use of public resources. Consequently, conflicts of interest are just one aspect in a wider variety of concerns. According to Mexican regulation, OICs are entrusted with receiving complaints and investigating anomalies so that later, the SFP can take the case to its regulatory conclusion beyond the legal implications that may arise. These legal implications are the responsibility of the legal areas of the different departments or of the Public Prosecutor's Office in the event that the SFP or OIC identify facts which imply criminal liability. Undoubtedly, this involves a process that would require transparency in order to prevent the same management structure form being the one that supervises, investigates and punishes (Arellano and Zamudio, 2009).

Faced with a lack of autonomous bodies outside the sphere of government influence, the task of supervising and 
correcting conflicts in Mexico is buried in the network and structure of central public administration. Not only are OICs entrusted with diverse tasks apart from supervising or receiving complaints about possible conflicts of interest, but their organizational instruments are basically reactionary, after the fact. In this context, the processes of prevention and prophylaxis are practically nonexistent given that the focal point of the OIC's attention is not the complexity that real, potential or apparent conflicts of interest entail, but with a broad range of problems related to a wide spectrum of regulation governing the behavior of government organizations which focuses specifically on corrupt practices (Arellano and Zamudio, 2009). As these authors indicate, the key to understanding OICs is that they probably face significant problems related to time and capacity, approach and concentration in order to prevent, deal with and correct the different types of conflicts of interest. This could allow us to explain why that there was no public knowledge of any action of this type in the 20002006 Administration.

Table 1 summarizes the main characteristics of the organizations responsible for conflicts of interest in the three countries we analyzed, their primary tasks and the instructional and inter-organizational relations through which they perform their duties.

\section{INSTRUMENTS FOR ORGANIZATIONAL CON- TROL}

After having analyzed the differences between the USA and Canada in respect to the organizational and institutional designs used to combat conflict of interest in its prevention, control and resolution phases, it would be valuable to look at the different organizational instruments that have emerged from these experiences to control the individual performance of public officials while carrying out their duties in the public interest.

One of the main aspects the international experiences we have analyzed focus their attention on is getting public officials to reveal their financial information and interests. In the case of the USA, this requirement has applied to members of Congress, Federal Judges and High ranking Public Officials of the Executive Branch since 1978. In Canada, this requirement applies to members of the House of Commons, Cabinet members, Ministers, Parliamentary Secretaries and Senators. In both cases, disclosing financial dealings is an underlying factor of prevention activities given that its objective is to detect and impede conflicts of interest prior to their being consummated as facts (Rhor, 1991). One important difference with respect to the declaration of financial standing demanded of Mexican public officials is that this financial disclosure in the USA and Canada extends to the public official's spouse and dependent children. This offers greater possibilities of identifying potential conflicts of interest in a timely fashion and consequently, implementing preemptive measures. ${ }^{9}$ The Canadian experience is even more interesting in view of the Confidential Certificate; a document that

\footnotetext{
${ }^{9}$ In Mexico, specifically in the case of Centralized Public Administration, the Declaration of Financial Standing applies to mid-level public officials through to the President of the Republic. For more details about the Declaration of Financial Standing and how it applies to the rest of the public sector see Art. 35 through 47 of the Ley Federal de Responsabilidades Administrativas de los Servidores Públicos (Federal Administrative Duties of Public Servants Law).
}

obliges the public official to analyze and inform on the economic and political interests that may come to affect the impartiality of their judgment. This document is used with extreme care by the corresponding office to carry out an ongoing systematic analysis of the public official's career for the purpose of identifying those moments when there is a possible risk of conflict of interest.

Another relevant aspect of the USA and Canadian experiences lies in the regulations governing post-employment of former public officials. The main worry with this kind of regulation is that these public officials may gain unfair advantage from their public duties once they have ceased working for the government. In the USA, there are strict limitations on the types of activities ex-public officials can engage in. These limitations establish periods of time (which can range up to 5 years) before a former public official can represent a private interest before the public sector on matters in which he or she has been involved in personally and substantially during their term in office. Similarly, they establish a time period of at least one year before an ex-public official may contact their old colleagues on behalf of a private interest. Another major worry in the USA is the phenomenon known as the "revolving door", which consists on the one hand of the possibility for personal enrichment through exploiting contacts and experiences acquired during tenure as a public official and on the other, corporate efforts to "capture" public agencies by way of promising private sector employment to public officials still in office (Rhor, 1991).

There is considerable worry in Canada too that public officials might attempt to take advantage of the information and experiences they acquired during their time in public office. However, different to the USA, the regulations that Canada has established to control this phenomenon are more lenient. This is due mainly to diverse factors which include greater job insecurity on the part of Canadian Cabinet members, ${ }^{10}$ their origin, ${ }^{11}$ the lower level of knowledge and control the cabinet member enjoys over the agency he or she controlled at the time they left office, as well as greater political vulnerability once they leave office. Not only do these differences between the USA and Canada have a bearing on the type of regulation that controls post-employment, but also on assigning liability when it comes to breaking these regulations. In Canada, given the greater level of political vulnerability (understood as the possibility to defend oneself publicly, not just legally) and the lower level of influence wielded by cabinet members when they leave office, all sanctions fall upon the public office holder who is still in service that has maintained some kind of forbidden contact with an ex-public official while the latter is usually given the "benefit of the doubt". The case is the opposite in the USA where ex-cabinet members enjoy greater power of control and negotiation when they leave office, and therefore criminal sanctions apply for violating post-employment regulations.

\footnotetext{
${ }^{10}$ In Canada, public officers in the federal arena are not appointed for a fixed term; instead they can be removed from office once there is a change of party in the Legislature.

${ }^{11}$ Cabinet Ministers are at the same time members of the House of Commons. This is not the case in the USA where Secretaries of State are usually drawn from the private sector and return there once their term is up.
} 
Table 1. Organizational and Institutional Instruments for the Control of Conflict of Interest

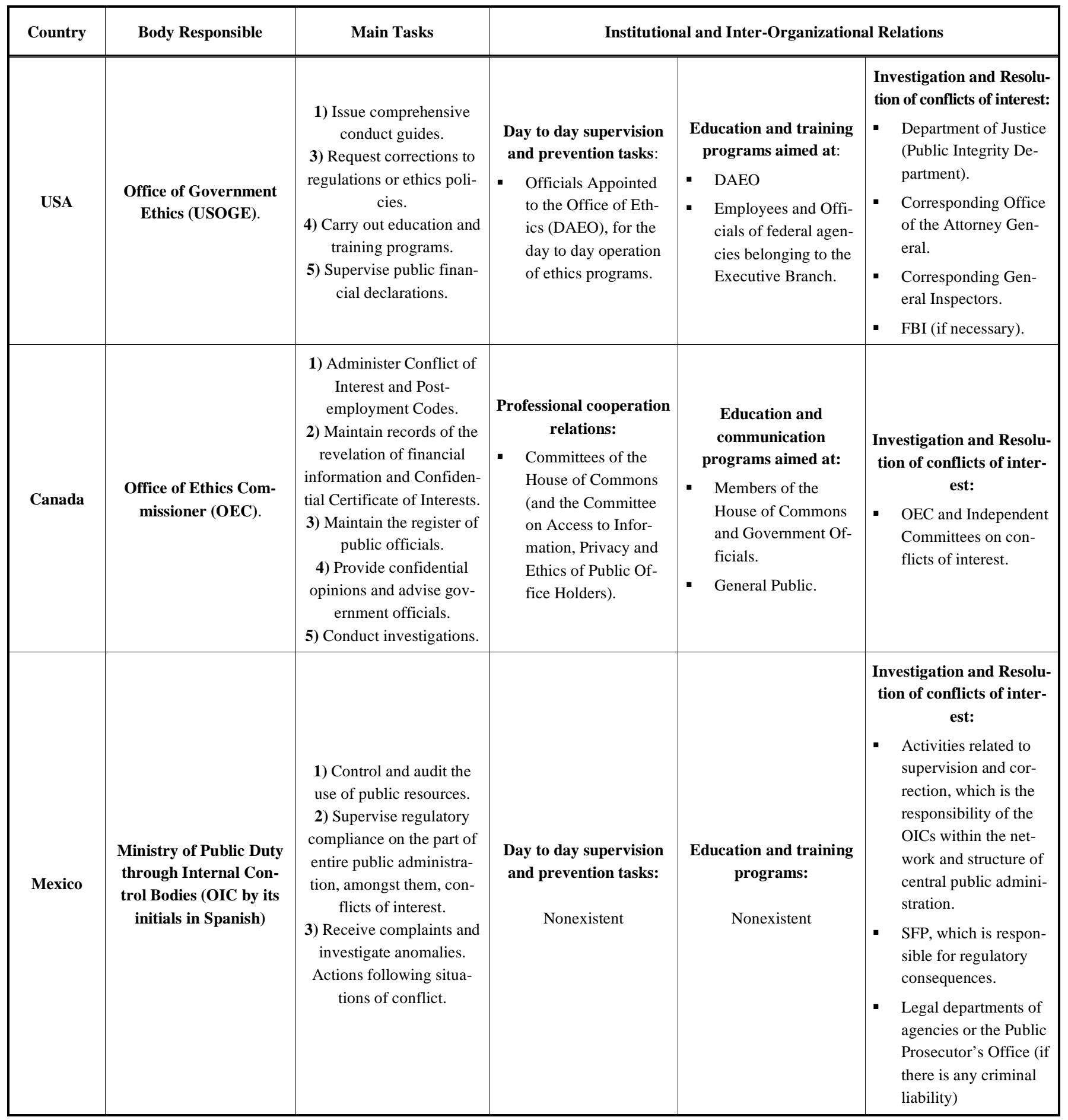

In Mexico, there is also this concern for regulating the post-employment activities of public officials. In fact, federal laws which regulate conflicting interests establish a time period of one year following finalization of public sector activities before receiving donations, services, goods and more generally speaking, taking advantage of the influence arising from their position. Despite these advances (significant as they may be), the mechanisms for proving compliance with these provisions, as well as for applying sanctions to those who infringe them, are still not clear.
Another thing that regulations governing conflict of interest in Canada and the USA have in common is linked to concerns that public officials may not be able to issue independent judgments or opinions, although both experiences demonstrate a different approach to the problem. In the USA, the relations that public officials share with private interests that provide them with some kind of income outside their government salary is considered an impediment to making impartial decisions in performance of their duties. Moreover, complementing public income with money from 
private sources is a criminal offence in the USA. The standards that govern employment or performance of a charge outside the government sector in Mexico follow a similar approach. However, the difference being that the regulatory framework is a little more lax in Mexico as it authorizes career public servants to carry out other activities in the public, social and private sectors provided that these do not impede or hamper their performance of the duties inherent to their current position or give rise to conflicts of interest. What remains unclear in Mexico is how to determine when an extraordinary activity impedes or hampers the public official's performance; what assumptions, requirements and procedures are necessary to conclude whether holding two or more jobs is compatible; and what is the limit beyond which a public official's interests are considered to be in conflict (this is an important aspect when you consider our previous statements that conflicts of interest are an ongoing and inevitable condition of all organizations).

Experiences in the USA however, happen to be diametrically opposed to those of Canada (and British parliamentary tradition) which consider that members of parliament who only receive income from public coffers are more likely to issue biased opinions that favor the government out of feeling indebted. An approach which allows public officials to receive income from the private sector is more likely to lead public officials to making sound, independent decisions that favor both the public interest and that of the electorate (Stark, 1992). The explanation of the differences between both types of control mechanisms lies not only with structural questions related to the system of government, but also with cultural aspects where an ethical or moral issue in one country is not viewed as such in another. These variables are fundamental, as is the issue of appearances we mentioned earlier, which in the case of Mexico must be understood if clear regulations are to be established to govern the accepting of income from the private sector.

Another tool to control the behavior and performance of public officials in respect to the potential appearance of conflicts of interest is linked to the possibility that they become embroiled in politics. This has been a driving concern in the USA, which is largely absent in Canada due to its system of government and the overlap between the Executive and Legislative Branches. The USA in effect completely prohibits public officials from participating in party elections at all three levels of government. This is because the carrot of gaining office through popular election could lead them to make improper, illegal or impartial decisions. While there are no specific regulations on this matter in Mexico, the Constitution does not allow high-ranking public officials (such as Secretaries, Undersecretaries of State, or heads of decentralized or de-concentrated bodies) to run for elected office unless they resign their positions at least 90 days prior to the election. Nevertheless, there is still a legal vacuum on these issues when it comes to mid-level public officials. This is no trivial matter; while the purpose may be to prohibit these mid-level public officials from participating in political activities for ethical questions, it could also come to detrimentally affect their individual and constitutional rights.

One last organizational control tool that we pause to look at in this section relates to accepting gifts and reimbursement of travel expenses incurred by non-government actors to public officials in certain circumstances. In this case, we will only focus on North American experiences which have dealt with this problem more severely than in other countries. One relevant aspect to keep in mind is that all transfer of economic valuables from private sources to a public official affect the appearance that they are committing an improper act and may send signals to the public that it may benefit the party who proffered the gift even though this may not imply a bribe in the strictest sense of the term (Roberts and Doss, 1992). Consequently, USA experiences have shown us that highly restrictive regulation governing the accepting of gifts and the reimbursement of travel expenses come close to prohibiting these practices. However, throughout the years regulation has been relaxed somewhat to establish maximum acceptable limits on the value of these gifts, as well as differentiate between the sources who make these transfers and the interests behind them. Greater flexibility with respect to this type of regulation is due in large part to the fact that sanctions and restrictions were not applied evenhandedly to the Executive and Legislative Branches. As a result, efforts have sought to even out (lower) the burden that both branches must carry. These reforms are also due to the practical impossibility of achieving complete and indiscriminant control in respect to restricting the accepting of economic valuables by public officials (Roberts and Doss, 1992).

Mexico also boasts federal regulations that govern the accepting of donations, which establishes the creation of a register of goods accepted by public officials. However, different to the USA which focuses on preventing the appearance of an improper act, in Mexico this register is used to study the evolution of a public official's financial standing. In other words, when there is suspicion that a prohibited act has come to pass and resulted in illegal gains on the part of the public official. Just like in the previous cases, the issue of prevention and preemption of conflicts are absent.

Table 2 to summarize the tools for organizational control that we presented in this section, as well as their main characteristics.

It remains clear that it would be difficult for any mechanism of this type to be exempt from design and implementation problems. One of the biggest failings of these mechanisms is precisely their low rate of application and compliance, as well as the possibility that the symbolic value of the restrictions on matters of conflicts of interest exceed their value as tools which allow the public to recover their confidence in the government (Roberts and Doss, 1992). These and other constraints to the elements for controlling conflicts of interest will be developed in the following section, as will the lessons we have learned from our analysis of international experiences which may prove useful to the case in Mexico.

\subsection{Final Observations}

In this last section we present a summary of what we have presented up until now in order to clarify the significant aspects of this work and to better identify the weaknesses of the international experiences and the lessons we might learn from them. A greater understanding of these experiences, their risks and teachings could be of some use in Mexico in order to progress toward a regulatory framework and an in- 
Table 2. Tools for Organizational Control

\begin{tabular}{|c|c|c|c|c|c|c|}
\hline & \multicolumn{6}{|c|}{ Tools for Organizational Control } \\
\hline Country & $\begin{array}{l}\text { Revealing of Financial } \\
\text { Information and Inter- } \\
\text { ests }\end{array}$ & $\begin{array}{l}\text { Confidential } \\
\text { Certification }\end{array}$ & $\begin{array}{l}\text { Post-Employment } \\
\text { Regulations }\end{array}$ & $\begin{array}{l}\text { Non-Government } \\
\text { Monetary Income }\end{array}$ & Political Activity & $\begin{array}{l}\text { Gifts and Reim- } \\
\text { bursement of } \\
\text { Travel Expenses }\end{array}$ \\
\hline USA & $\begin{array}{l}\text { Objective: } \\
\text { - Detect and prevent. } \\
\text { - Preventative actions. } \\
\text { Applies to:* } \\
\text { - All members of } \\
\text { Congress. } \\
\text { - Federal Judges. } \\
\text { - High level public } \\
\text { officials (Executive } \\
\text { Branch). } \\
\text { * Includes spouse and } \\
\text { dependant children } \\
\text { of public official. }\end{array}$ & Does NOT apply & 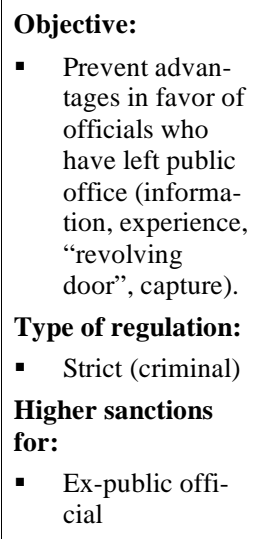 & $\begin{array}{l}\text { Objective: } \\
\text { - } \quad \text { Prevent public } \\
\text { officials from } \\
\text { being unable to } \\
\text { issue independ- } \\
\text { ent judgments } \\
\text { and opinions. } \\
\text { Acceptance: } \\
\text { - } \quad \text { NOT Permitted }\end{array}$ & $\begin{array}{l}\text { Objective: } \\
\text { - } \quad \text { Prevent unfair, } \\
\text { improper or im- } \\
\text { partial decisions } \\
\text { with the view to } \\
\text { obtaining a popu- } \\
\text { larly elected posi- } \\
\text { tion. } \\
\text { Acceptance } \\
\text { - } \quad \text { NOT Permitted }\end{array}$ & $\begin{array}{l}\text { Objective: } \\
\text { - } \quad \text { Prevent corrupt } \\
\text { or seemingly } \\
\text { improper ac- } \\
\text { tions. } \\
\text { Acceptance: } \\
\text { - } \quad \text { NOT Permitted } \\
\text { above certain } \\
\text { maximum price } \\
\text { ranges, origins } \\
\text { and interests un- } \\
\text { derlying the ori- } \\
\text { gin. }\end{array}$ \\
\hline Canada & $\begin{array}{l}\text { Objective: } \\
\text { - } \quad \text { Detect and prevent. } \\
\text { - Preventative actions. } \\
\text { Applies to:* } \\
\text { - House of Commons. } \\
\text { - Cabinet and Minis- } \\
\text { ters. } \\
\text { - Parliamentary secre- } \\
\text { taries · Senators. } \\
\text { * Includes spouse and } \\
\text { dependant children } \\
\text { of public official. }\end{array}$ & $\begin{array}{l}\text { Objective: } \\
\text { - Inform on the } \\
\text { economic and } \\
\text { political inter- } \\
\text { ests which can } \\
\text { at some future } \\
\text { point affect } \\
\text { the impartial- } \\
\text { ity of the pub- } \\
\text { lic official's } \\
\text { judgment. }\end{array}$ & 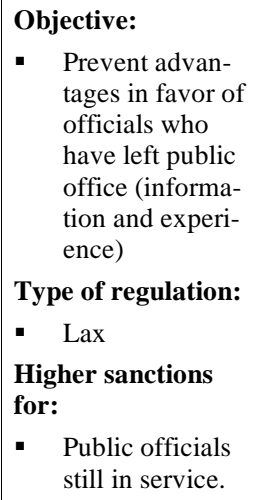 & $\begin{array}{l}\text { Objective: } \\
\text { - } \quad \text { Prevent public } \\
\text { officials from } \\
\text { being unable to } \\
\text { issue independ- } \\
\text { ent judgments } \\
\text { and opinions. } \\
\text { Acceptance: } \\
\text { - } \quad \text { Permitted }\end{array}$ & Does NOT apply & 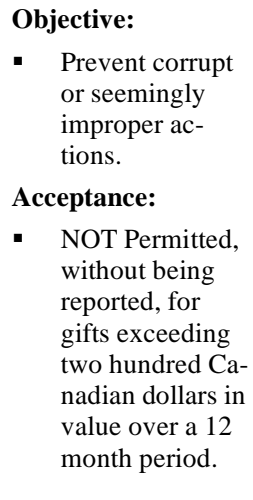 \\
\hline
\end{tabular}

stitutional and organizational design aimed at combating conflicts of interest in the federal public administration.

To begin with, it is important to identify the different types of conflicts of interest -real, apparent and potential-, accept their inherent and inevitable presence in all organizations and recognize their differences to related concepts such as corruption and influence peddling. These must be the starting point of all recommendations for the case in Mexico 
in the idea that a better understanding of this phenomenon, which is so problematic and interrelated with other similar ones, would allow us to evolve toward complex and heterogeneous regimens in order to deal with conflicts of interest. In this way it would also be possible to design and implement mechanisms for protection, prophylaxis and control of conflicts of interest, and not just mechanisms and tools to punish this type of behavior, which is currently the case.

The experiences of the USA and Canada have shown us the importance of punishing conflicts of interest, but more importantly, they have also demonstrated the importance of preventing and avoiding that these occur in the first place. This is one aspect that is essential for Mexico where there is not pragmatic vision of this phenomenon resulting in the absence of prevention measures in the prevailing logic of the regulatory framework governing the matter. This explains in part the lack of a nonstatutory regimen in the phases of prevention and preemption; in other words, a type of code of ethical conduct transformed into "organizational mandates" which must complement the regulatory regimen aimed at punishing and sanctioning conflicts of interest once consummated and come to light.

Despite the benefits that a mixed regimen of statutory and nonstatutory may hold, not to mention a combination of administrative and criminal sanctions, the international experiences we looked at here have shown us certain limitations to regulatory tool in the fight against conflicts of interest. As Anechiarico and Jacobs (1996) point out, one of the most risky regulations governing conflicts of interest provides for a panoptic approach to control this phenomenon. Not only do these authors warn that it is impossible to control, supervise and prevent each and every type of behavior that might give rise to conflicts of interest, but also of the limited impact these regulations have in particular, on the functioning of public administrations in general. Concerning reductions of conflicts of interest, these authors reveal that the laws which seek to prevent conflicts and those linked to revealing financial information suffer two main problems: a) the probability of detecting a real conflict of interest depends on routine, substantive and detailed investigation, which is not always carried out; b) regulations on ethics show a very low compliance rate given the unlikelihood of catching those who break them and that insufficient incentives have been created to discourage these types of practices.

Anechiarico and Jacobs (1996) identify the following risks with respect to impact on public administration with special reference to organizational control mechanisms. Firstly, these types of controls may have a symbolic rather than real impact on the performance of public officials given the effort to translate a "mythical code" of government integrity which governs their day to day conduct. As a consequence, in many cases, the regulations have become more relaxed so as not to interfere in the everyday operations of public administration. This has resulted in excessive preoccupation with legal and regulatory questions which, nonetheless, have had little real impact on public confidence (Roberts and Doss, 1992). These authors reveal that, from a practical viewpoint, the cost of failing to apply and comply with regulations governing conflicts of interest may have greater weight than the damage inflicted on the legitimacy of decision making and the actions of public organizations than by the actual appearance of these types of conflicts. The second risk to keep in mind is that the requirements to reveal financial information, the regulations on post-employment, the call to divest property, shares or resign positions may cause conflicts (including apparent ones) and have a negative effect on recruitment and retention of personnel in the public arena. In addition, these control mechanisms may also affect a public official's morality (it is worth noting that the supposed tactic in the USA on matters of conflict of interest is that public officials are guilty until they prove otherwise) and lead to "slower and more defensive" decision making (Anechiarico and Jacobs, 1996).

Finally, we would like to conclude with a number of general recommendations aimed at developing countries which intend to focus on combating conflicts of interest, among them Mexico. First and foremost we must begin clearly with respect to the mid and long term objectives, but also pragmatically regarding their scope. And speaking of pragmatism, these regulations must not be seen as a cure-all, much less as a political weapon. Given the implied cost of creating an autonomous agency which specializes in conflicts of interest (we assume that in Mexico the current focus of giving responsibility for this issue to the OICs is simple impractical) supervision mechanisms must be created that can be put into practice realistically, economically and effectively. Regarding medium term objectives, this agency could create a culture of confidential, financial reporting and bring about random (with very clear rules), public (or at least with a clear and trustworthy process) and systematic supervision. Long term goals would have to consider a more sophisticated organizational routine which would also imply systematic evaluation of even more diverse and complex situations. In sum, what is recommended for developing countries is a clear strategic vision (aimed at prevention and generating a culture of ethics) that is instrumentally viable; in other words, systematic and random supervision with criteria open to the public, as well as a vision where prevention and education prevail in an organizational culture that allows for public "watch dogs".

\section{REFERENCES}

Ahrne, G., \& Nils, B. (2004). Soft regulation from an organizational perspective. In Morth U. (Eds.), Soft Law in Governance and Regulation. Edward Elgar: Cheltenham.

Anderson, C. (1992). The Place of Principles in Policy Analysis. The Moral Dimensions of Public Policy Choice. Beyond the Market Paradigm. University of Pittsburgh Press: Pittsburgh.

Anechiarico, F., \& Jacobs, J. (1996). The Pursuit of Absolute Integrity, How Corruption Control Makes Government Ineffective. The University of Chicago Press: Chicago.

Arellano-Gault, D. (2000). Reformando al Gobierno. Una Visión Organizacional del Cambio Gubernamental. Miguel Angel Porrúa: Mexico.

Arellano-Gault, D., \& Zamudio-Gonzalez, L. (2009). Los dilemas organizacionales e institucionales de las regulaciones para contener los conflictos de interés en una democracia: una aproximación comparativa entre Canadá, EUA y Mexico. Convergencia 16(49), 145-173.

Atkinson, M., \& Mancuso, M. (1991). Conflict of interest in Britain and United States: an institucional argument. Legislative Studies Quarterly 16(4), 471-493.

Atkinson, M., \& Mancuso, M. (1985). Do we need a code of conduct for politicians? The search for an elite political culture of corruption in Canada. Canadian Journal of Political Science 18(3), 459-480.

Brunsson, N. (1989). The organization of hypocrisy. Chichester. John Wiley \& Sons.

Cámara de Diputados del H. Congreso de la Unión, Código Penal Federal, últimas reformas publicadas, en el Diario Oficial de la Federación el 30 de Junio de 2006, pp. 1-139, Mexico. 
Christensen, T., \& Per L. (2001). New Public Management. The Transformation of Ideas and Practice. Aldershot: Ashate.

Crozier, M., \& Friedberg E. (1989). El actor y el sistema. Editorial Alianza, Mexico.

Frederickson, G. (1997). The Spirit of Public Administration. Jossey-Bass Publishers: San Francisco.

Gilman, S., Joseph, J., \& Raven, C. (2002). Conflict of Interest: Balancing Appearances, Intentions and Values. Documento Preparado Para La Reunión de Abril. OECD. París. Francia.

Graham, G. (1974). Ethical Guidelines for Public Administrators: Observations on rules of the game. Public Administration Review 34(1), 9092.

Gregory, R. (1999). Social Capital Theory and Administrative Reform: Maintaining Ethical Probity in Public Service. Public Administration Review 59(1), 63-75.

Kliksberg, B. (2006). Más ética, más Desarrollo. Temas Grupo Editorial SRL, Buenos Aires: Argentina.

Levi-Faur, D. (2005). The global difusión of regulatory capitalism. Annals $598,12-32$.

Luhmann, N. (1997). Organización y Decisión. Anthropos: Mexico.

Ley Federal de Responsabilidades de los Servidores Públicos, última reforma publicada en el Diario Oficial de la Federación el 13 de Junio 2003, pp 1-42, Mexico.

Ley Federal de Responsabilidades Administrativas de los Servidores Públicos, última reforma publicada en el Diario Oficial de la Federación el 21 de Agosto 2006, pp 1-25, Mexico.

Majone, G. (1997). From the positive to the regulatory state: causes and consequences of changes in the mode of governance. Journal of Public Policy 17(2), 139-167.

March, J., \& Joan, O. (1979). Ambiguity and Choice in organizations. Scandinavian University Press: Oslo.

Office of Ethics Commissioner (2006), http://www.parl.gc.ca/oec, web page as October 20, 2006

Organización para la Cooperación y el Desarrollo Económicos (2005), Policy Brief, OECD Guidelines for managing Conflict of Interest in the Public Service, pp 1-8, Paris.
Pffefer, J. (1994). Managing with Power. Politics and Influence in Organizations. Harvard Business School Press: Cambridge.

Rhor, J. (1991). Ethical Issue in French Public Administration: A Comparative Study. Public Administration Review 51(4), 283-297.

Roberts, R. (2001). Ethics in U.S. Government: an Encyclopedia of Investigations, Scandals, Reforms, and Legislation. Greenwood Press: New York.

Roberts, R., \& Doss, M. (1992). Public service and private hospitality: A case study in federal conflict-of-interest reform. Public Administration Review 52(3), 260-270.

Scott, R. (2000). Institutions and Organizations. Sage: Thousand Oaks.

Simon, H. (1947). El Comportamiento Administrativo. Ariel: Madrid.

Stark, A. (1992). Public sector conflict of interest at the federal level in Canada and the U.S.: Differences in understanding and approach. Public Administration Review 52(5), 427-437.

Stark, A. (1997). Beyond Quid Pro Quo: What is wrong with private gain from public office. American Political Science Review 97(1), 108

Thompson, D. (1992). Paradoxes of Government Ethics. Public Administration Review 52(3), 254-259.

United State Office of Government Ethics (2006), http://www.usoge.gov/home.html, web page as September 28, 2006.

Ventriss, C. (2000). The Relevance of Public Ethics to Administration and Policy. Handbook of Administrative Ethics. Second Edition Revised and Expanded, Marcel Dekker: Nueva York.

Wade, M. (1992). Hume's Theory of Justice and the Role of Public Policy. The Moral Dimensions of Public Policy Choice. Beyond the Market Paradigm, University of Pittsburgh Press: Pittsburg.

Walter, J. (1981). The Ethics in Government Act, Conflict of Interest Laws and Presidential Recruiting. Public Administration Review 41(6), 659-665.

Williams, S. (1985). Conflict of Interest: The Ethical Dilemma in Politics. Sage: Gower.

Williamson, O. (1983). Market and Hierarchies. Free Press: New York.

(C) Arellano-Gault et al.; Licensee Bentham Open.

This is an open access article licensed under the terms of the Creative Commons Attribution Non-Commercial License (http://creativecommons.org/licenses/by-nc/3.0/) which permits unrestricted, non-commercial use, distribution and reproduction in any medium, provided the work is properly cited. 